\title{
EVALUATION OF MIDDLE TERM GREENHOUSE GAS (GHG) MITIGATION POTENTIAL OF BIRCH PLANTATIONS WITH MINERAL AND ORGANIC SOILS
}

Andis Lazdins, Guntars Snepsts, Aldis Butlers, Dana Purvina, Zaiga Anna Zvaigzne, Ieva Licite

Latvian State Forest Research Institute "Silava", Latvia

andis.lazdins@silava.lv, guntars.snepsts@ silava.lv, aldis.butlers@ silava.lv, dana.purvina@ silava.lv, zaiga.zvaigzne@silava.lv, ieva.licite@silava.lv

\begin{abstract}
The study compares 9 forest management scenarios in birch plantations in cropland and grassland with mineral and organic soils. Calculation period is 40 years for all scenarios. The study proves that establishment of birch plantations leads to reduction of greenhouse gas (GHG) emissions by 317-1776 tons of $\mathrm{CO}_{2}$ eq. ha ${ }^{-1}$ or 7.9-44.4 tons of $\mathrm{CO} 2$ eq. ha $^{-1}$ per year. The reduction of GHG emissions in birch plantations is significantly influenced by growth conditions - in organic soils GHG emission reduction is 6 times higher than in mineral soils. In plantations with mineral soils most of the GHG emission reductions occur during 40 years after the establishment. In organic soils GHG emission reduction continues steadily due to reduction in GHG emissions from soils compared to alternative management scenarios (grassland or cropland). Harvested wood products and the substitution effect of biofuels play an important role in reducing GHG emissions, in particular through the assumption that wood products are recycled into biofuels at the end of their useful life. Recommended type of soil preparation in the most cases is mounding, but taking into account soil scarification costs, the number of target trees in the plantation must be reduced (down to 1500 per ha $^{-1}$ ). Early tending, felling of young stands and regenerative felling must also be adapted to growing conditions by managing more intensively areas with fertile soils and less intensively - plantations with poor soils. In more fertile soils higher planting density may increase $\mathrm{CO}_{2}$ removals in the middle term. When planting 1500-2000 seedlings ha ${ }^{-1}$, moderately fertile soils ensures higher $\mathrm{CO}_{2}$ removals. According to the study results establishment of birch plantations in farmland is one of the most effective solutions for reducing GHG emissions in the land use, land use change and forestry (LULUCF), as well as in agriculture sector, especially, if organic soils are afforested.
\end{abstract}

Keywords: plantation forests, greenhouse gas emissions, climate change mitigation, organic soil.

\section{Introduction}

Afforestation is one of the main tools to implement climate neutrality targets in 2050. According to Doelman et al. (2019), GHG mitigation potential of afforestation is $4.9 \mathrm{Gt} \mathrm{CO}_{2} \mathrm{yr}^{-1}$. Afforestation also reduces the overall costs of mitigation policy [1]. Afforestation is a cost-effective and readily available climate change mitigation measure. In recent studies afforestation is presented as a major solution to limit climate change. However, estimates of afforestation potential vary widely hampering broad use of the afforestation potential, particularly, the mitigation potential is not estimated using methodology harmonized with GHG inventories [1;2].

Latvia is located at the interface between temperate coniferous forests and Central European broadleaf forests. In the climatic conditions typical of Latvia, the final stage of natural succession is forest. Afforestation of agricultural land is a purposefully promoted succession that results in the creation of forest ecosystems that replace man-made artificial agricultural landscapes [3].

According to the National forest inventory (NFI), the total area of naturally overgrown agricultural land during the last 25 years exceeds $300 \mathrm{kha}$. Birch and grey alder dominate in the naturally afforested former agricultural areas, which confirms the status of pioneer species of these trees [4].

Despite the fact that the fertility of former agricultural lands is usually better than that of forest lands, the annual increase of the stock in naturally afforested agricultural lands is small [5]. For example, birch, which is known as a very fast-growing and productive tree species and whose current growth can exceed $10 \mathrm{~m}^{3} \mathrm{ha}^{-1} \mathrm{yr}^{-1}$, according to NFI, produces in naturally afforested lands only $1.1 \mathrm{~m}^{3} \mathrm{ha}^{-1} \mathrm{yr}^{-1}$. Significantly smaller increment is found in all age groups in naturally afforested areas [2].

The dynamics of afforestation in Latvia is largely determined by the availability of the European Union (EU) and state support to afforestation and support to maintenance of perennial grasslands, which prevents afforestation of lands not used in crop production. The first significant support for afforestation of agricultural land in Latvia became available starting from 2000, within the framework of the agricultural and rural development program SAPARD. From 2001 to 2007, this program promoted the afforestation of $4.0 \mathrm{kha}$ of agricultural land [6]. After joining to the EU, more funds became available to Latvia, including support to afforestation of agricultural land. From 2004 to 2007, 3.6 kha of 
afforested land were afforested under the European Agricultural Guidance and Guarantee Fund (EAGGF), and from 2007 to 2011 another 9.6 kha under the European Agricultural Fund for Rural Development (EAFRD). Notably, that the increase of naturally afforested areas during this period was at least 10 times higher.

Some agricultural land has not been managed (not used for crop production) for almost 30 years. All this time, unmanaged land has brought virtually no benefit to landowners or to the national economy as a whole, unless the area payments by the EU can be considered as a benefit. During this time, each hectare of land planted with birch can produce up to $300 \mathrm{~m}^{3}$ of wood and provide the first income to the owners due to selling of wood obtained during the first commercial thinning. After another 10-20 years, the birch stand can be felled in regeneration felling. Each 10 kha of unused agricultural land planted with birch can provide about 1 mill. $\mathrm{m}^{3}$ in commercial felling and about 4 mill. $\mathrm{m}^{3}$ in regenerative felling, including 2-2.8 mill. $\mathrm{m}^{3}$ of veneer logs. Production of wood resources in birch plantations in unused agricultural land creates opportunities to increase the processing capacity, build new factories and contribute to the state by increasing gross domestic product, production and exports, as well as creating new jobs [4]. No less important is the potential role of birch stands and other afforestation in achieving GHG emission reduction targets [5].

There are still about $300 \mathrm{kha}$ of non-forested agricultural land in Latvia, which meets the criteria of low-valued areas accessible for afforestation [7]. About 130 thousand ha of agricultural areas have organic soils. The potential for reducing GHG emissions in such areas is particularly high.

Currently, the regulatory framework in Latvia allows registration of stands planted on agricultural lands as plantation forests. This permits different management measures to be applied, and also does not exclude the possibility to return these areas to agricultural production [4]. The establishment of medium or short rotation plantation forests in unused agricultural areas is still one of the most effective solutions for managing a property efficiently and relatively cheaply [4].

Birch plantations are also one of the most effective solutions for achieving GHG emission reduction targets in the land use, land use change and forestry (LULUCF) sector, ensuring $\mathrm{CO}_{2}$ removals in all carbon pools and reducing GHG emissions from organic soils [1;8].

The scope of the study is to estimate GHG mitigation potential of birch plantations under different management conditions un depending on the initial land use and nutritional regime using methodologies harmonized with the National GHG inventory.

\section{Materials and methods}

Assumptions on forest growth in the study are elaborated using the AGM model [9]. These assumptions are optimized for the highest economic value of forest in the given conditions. Three different management approaches are compared in the growth conditions representing the highest (best), moderate (good) and lowest (satisfactory) tree height at certain age in the highest forest site index (bonity) class, which is typical for afforested lands, if appropriate management measures are applied. the summary of the tree growth and management assumptions is provided in Table 1.

Table 1

Management and growth rate assumptions

\begin{tabular}{|c|c|c|c|c|c|c|}
\hline $\begin{array}{c}\text { Growth } \\
\text { conditions }\end{array}$ & Variant & $\begin{array}{c}\text { Number of } \\
\text { planted } \\
\text { trees }\end{array}$ & $\begin{array}{c}\text { Thinning } \\
\text { age }\end{array}$ & $\begin{array}{c}\text { Thinning } \\
\text { intensity }\end{array}$ & $\begin{array}{c}\text { Final } \\
\text { felling } \\
\text { age }\end{array}$ & $\begin{array}{c}\text { Growing stock } \\
\text { at final felling, } \\
\mathbf{m}^{\mathbf{3}} \mathbf{h a}^{-\mathbf{1}}\end{array}$ \\
\hline \multirow{3}{*}{ Best } & 1 & 2500 & 25 & $32 \%$ & 50 & 597 \\
\cline { 2 - 7 } & 2 & 2000 & 25 & $32 \%$ & 45 & 541 \\
\cline { 2 - 7 } & 3 & 1500 & 25 & $29 \%$ & 40 & 483 \\
\hline \multirow{3}{*}{ Good } & 4 & 2500 & 25 & $30 \%$ & 55 & 637 \\
\cline { 2 - 7 } & 5 & 2000 & 25 & $30 \%$ & 50 & 578 \\
\hline \multirow{3}{*}{ Satisfactory } & 6 & 1500 & 30 & $32 \%$ & 45 & 476 \\
\cline { 2 - 7 } & 7 & 2500 & 30 & $31 \%$ & 60 & 646 \\
\cline { 2 - 7 } & 8 & 2000 & 30 & $32 \%$ & 55 & 577 \\
\hline
\end{tabular}


The output of sawlogs, pulpwood and firewood in thinning and regenerative felling is calculated according to the study by the Joint stock company "Latvia's state forests" providing equations for calculation of output of an assortment according to the average volume of extracted trees [10]. It is also considered that demolition wood is used as biofuel after end-of-life replacing fossil fuel. Harvesting residues are left in the field according to the assumptions.

Initial conditions and alternate scenarios, at the same time, are grassland or cropland with well drained organic or mineral soil. Initial carbon stock in mineral soil $\left(60\right.$ tons $\left.\mathrm{C} \mathrm{ha}^{-1}\right)$ is estimated using Yasso model as an average steady state value. No difference is set between cropland and grassland, following the results of earlier studies [11]. Assumptions on carbon stock change in mineral soils due to afforestation are estimated using Yasso model within the scope of elaboration of the National Forest Reference Level [12]. GHG emissions from organic soils are estimated according to the Intergovernmental Panel on Climate Change guidelines [13]. In croplands the methane $\left(\mathrm{CH}_{4}\right)$ emission factor for ditches is 1165.00 , area of drainage ditches $-5 \%$, nitrous oxide $\left(\mathrm{N}_{2} \mathrm{O}\right)-13.00 \mathrm{~kg} \mathrm{~N}_{2} \mathrm{O} \mathrm{ha}{ }^{-1}$ $\mathrm{yr}^{-1}$ and carbon dioxide $\left(\mathrm{CO}_{2}\right)-7.90$ tons $\mathrm{CO}_{2}-\mathrm{C} \mathrm{ha}^{-1} \mathrm{yr}^{-1}$. In grasslands the $\mathrm{CH}_{4}$ emission factor for ditches is 1165.00 , area of drainage ditches $-5 \%, \mathrm{CH}_{4}$ emission factor for remaining area $-16.00 \mathrm{~kg}$ $\mathrm{CH}_{4} \mathrm{ha}^{-1} \mathrm{yr}^{-1}, \mathrm{~N}_{2} \mathrm{O}-8.20 \mathrm{~kg} \mathrm{~N}_{2} \mathrm{O} \mathrm{ha}^{-1} \mathrm{yr}^{-1}$ and $\mathrm{CO}_{2}-6.10$ tons $\mathrm{CO}_{2}-\mathrm{C} \mathrm{ha}^{-1} \mathrm{yr}^{-1}$.

The assumed carbon stock in litter in afforested area at the steady stage is 12.14 tons $\mathrm{C} \mathrm{ha}^{-1}$, transition period 150 years according to assumptions applied in the National GHG inventory [1]. Carbon stock in dead wood is calculated using the AGM model, which provides information on natural mortality and dimensions of extracted trees, transformed into carbon stock using biomass expansion factors $[13 ; 14]$. Decomposition of dead wood assumed in calculation is 20 years. In forest land the $\mathrm{CH}_{4}$ emission factor for ditches is 217.00 , area of drainage ditches $-3 \%, \mathrm{CH}_{4}$ emission factor for remaining area $-2.50 \mathrm{~kg} \mathrm{CH}_{4} \mathrm{ha}^{-1} \mathrm{yr}^{-1}, \mathrm{~N}_{2} \mathrm{O}-4.40 \mathrm{~kg} \mathrm{~N}_{2} \mathrm{O} \mathrm{ha}^{-1} \mathrm{yr}^{-1}$ and $\mathrm{CO}_{2}-0.52$ tons $\mathrm{CO}_{2}-\mathrm{C} \mathrm{ha}^{-1} \mathrm{yr}^{-1}$ according to the National GHG inventory [14].

The methodology for calculation of carbon turnover in harvested wood products from afforested lands is transferred from National GHG inventory, assuming 35 years long half life for sawn-wood, 25 years - for plate-wood and 2 years - for pulpwood [14]. No difference is made between locally consumed and exported roundwood. Biofuel replacement effect is estimated by comparison of forest biofuel and natural gas. Main assumptions applied in calculation of the replacement effect are provided in Table 2. GHG equivalent of $\mathrm{CH}_{4}$ applied in the calculations is 25 and $\mathrm{GHG}$ equivalent for $\mathrm{N}_{2} \mathrm{O}-298$ [15].

Table 2

Assumptions for calculation of the replacement effect of forest biofuel [16]

\begin{tabular}{|l|l|l|l|}
\hline \multicolumn{1}{|c|}{ Parameter } & \multicolumn{1}{|c|}{ Measurement unit } & \multicolumn{1}{|c|}{ Natural gas } & \multicolumn{1}{c|}{$\begin{array}{c}\text { Forest } \\
\text { biofuel }\end{array}$} \\
\hline Heat value & $\begin{array}{l}\text { MWh m}{ }^{-3} \text { for natural gas and } \mathrm{MWh} \mathrm{ton}^{-1} \\
\text { for the forest biofuel }\end{array}$ & 0.00936 & 4.90000 \\
\hline Boiler efficiency & - & $85 \%$ & $80 \%$ \\
\hline $\mathrm{CO}_{2}$ emission factor & tons $\mathrm{CO}_{2} \mathrm{MWh}^{-1}$ & 0.1984470 & - \\
\hline $\mathrm{N}_{2} \mathrm{O}$ emission factor & tons $\mathrm{N}_{2} \mathrm{O} \mathrm{MWh}^{-1}$ & 0.0000004 & 0.0000144 \\
\hline $\mathrm{CH}_{4}$ emission factor & tons $\mathrm{CH}_{4} \mathrm{MWh}^{-1}$ & 0.0000036 & 0.0001080 \\
\hline
\end{tabular}

\section{Results and discussion}

Depending on the implemented scenario, the reduction of GHG emissions in 40 years is 7.9-44.4 tons of $\mathrm{CO}_{2} \mathrm{ha}^{-1} \mathrm{yr}^{-1}$, including 0.4-3.0 tons $\mathrm{ha}^{-1} \mathrm{yr}^{-1}-$ in dead wood, 0.4-3.2 tons $\mathrm{ha}^{-1} \mathrm{yr}^{-1}-$ in HWP, 0.3 tons ha ${ }^{-1} \mathrm{yr}^{-1}-$ in litter, 0.0-9.8 tons ha- $\mathrm{yr}^{-1}-$ in living biomass, 0.2-1.0 tons $\mathrm{ha}^{-1} \mathrm{yr}^{-1}-$ due to substitution effect and 0.9-33.1 tons ha-1 per year - in the soil. $\mathrm{CO}_{2}$ removal in living biomass depends on the rotation period - the closer it is to the end of the calculation period, the lower the net $\mathrm{CO}_{2}$ removals in living biomass are and more $\mathrm{CO}_{2}$ is removed in dead wood and HWP pool.

The largest reduction of GHG emissions in the most fertile soils (the best growth conditions according to Table 1) is ensured by planting 2500 seedlings per ha, but in the moderately fertile (good conditions) and less fertile soils (satisfactory conditions) - by planting of 1500-2000 seedlings ha ${ }^{-1}$ due to a longer rotation period. There are no significant differences in the calculated GHG emission 
reduction between afforestation of cropland and grassland with mineral soil, although in practice the difference may be significant given the possible different initial carbon stock in soil. Afforestation of cropland with organic soils results in a significantly higher reduction of GHG emissions than afforestation of grasslands with organic soils due to a significantly higher reduction of GHG emissions from the soil. The forest management alternatives do not have significant impact in this case, so it is useful to plant a smaller number of trees in organic soils to reduce afforestation cost. Afforestation of organic soils ensures 6 times higher average annual emission reductions compared to afforestation of mineral soils.

The cumulative reduction of GHG emissions over 40 years is $316-1776$ tons $\mathrm{C}^{-1}$ (Table 3 ), including 16-105 tons ha ${ }^{-1}$ - in dead wood, 14-124 tons ha ${ }^{-1}$ - in wood products, 12 tons ha ${ }^{-1}-$ in litter, 0-394 tons ha ${ }^{-1}$ - in living biomass, 8-39 tons ha ${ }^{-1}$ - due to replacement effect and 37-1323 tons ha ${ }^{-1}$ in soil.

It should be taken into account that the $\mathrm{CO}_{2}$ emission factor developed in Latvia is used for forests, but the default GHG emission factors for arable lands and grasslands, therefore the reduction of GHG emissions after the development of national emission factors for organic soils may differ from the currently estimated values.

Table 3

Net GHG emission reduction due to afforestation

\begin{tabular}{|c|c|c|c|c|c|}
\hline \multirow{3}{*}{$\begin{array}{c}\text { Growth } \\
\text { conditions }\end{array}$} & \multirow{2}{*}{ Soil type } & \multirow{2}{*}{ Initial land use } & \multicolumn{3}{|c|}{ Number of trees planted per ha } \\
\cline { 3 - 6 } & & & 1500 & 2000 & 2500 \\
\hline \multirow{3}{*}{ Best } & \multirow{2}{*}{ Mineral soil } & Cropland & 317 & 389 & 490 \\
\cline { 3 - 6 } & & Grassland & 317 & 389 & 490 \\
\cline { 3 - 6 } & \multirow{2}{*}{ Organic soil } & Cropland & 1603 & 1675 & 1776 \\
\cline { 3 - 6 } & & Grassland & 1264 & 1336 & 1437 \\
\hline \multirow{3}{*}{ Good } & \multirow{2}{*}{ Mineral soil } & Cropland & 362 & 466 & 459 \\
\cline { 3 - 6 } & \multirow{2}{*}{ Organic soil } & Grassland & 362 & 466 & 459 \\
\cline { 3 - 6 } & & Cropland & 1648 & 1752 & 1745 \\
\cline { 3 - 6 } & \multirow{2}{*}{ Mineral soil } & Grassland & 1309 & 1413 & 1406 \\
\cline { 3 - 6 } & & Cropland & 334 & 426 & 423 \\
\cline { 3 - 6 } & \multirow{2}{*}{ Organic soil } & Crassland & 334 & 426 & 423 \\
\cline { 3 - 6 } & & Grassland & 1620 & 1712 & 1708 \\
\hline
\end{tabular}

In case of afforestation of organic soils, significant difference is found due to reduction of GHG emissions from soils between cropland and grassland, respectively, 24.6 tons of $\mathrm{CO}_{2}$ eq. ha ${ }^{-1} \mathrm{yr}^{-1}$ and 33.1 tons of $\mathrm{CO}_{2}$ eq. ha $^{-1} \mathrm{yr}^{-1}$.

The impact of plantation density on the GHG emission reduction was evaluated by comparing the cumulative GHG emission reduction in afforested mineral soils. By planting 1500 trees $\mathrm{ha}^{-1}$, the reduction of GHG emissions during 40 years is significantly lower than in other variants, which is mainly related to commercial thinning, when $30 \%$ of growing trees are felled. The largest reduction in GHG emissions is ensured by higher density (2000-2500 ha-1); however, increase of the planting density is associated with increase of the risk of snow and wind damages, as well as reduction of proportion of valuable assortments in regenerative felling.

An alternative solution to increase the $\mathrm{CO}_{2}$ removals by planting 1500 trees ha- ${ }^{-1}$ is to reduce the intensity of commercial thinning, e.g., by using a compact class forest machines requiring narrower strip-roads and proportionally smaller number of trees has to be felled on strip-roads. Planting of 1500 trees $\mathrm{ha}^{-1}$ increases the profitability of forest management due to smaller establishment costs, quicker growth and higher share of valuable assortments. It should be taken into account that reduction of the number of planted trees is also the only technically feasible solution in the most of organic soils and wet mineral soils.

Comparing the reduction of GHG emissions in different growth conditions, the largest GHG emission reduction is expected in the most fertile soils. This expectation may be corrected by the initial 
carbon stock in soil - poor soils may be more depleted, respectively, they have a higher carbon sequestration potential.

\section{Conclusions}

1. The establishment of birch plantations over 40 years allows to reduce GHG emissions by 317-1776 tons of $\mathrm{CO} 2$ eq. ha $^{-1}$, depending on the soil type, land use and planting thickness; respectively, afforestation of 1000 ha with birch would reduce GHG emissions by 0.3-1.8 mill. tons of $\mathrm{CO}_{2}$ eq.

2. The reduction of GHG emissions through the establishment of birch plantations is significantly affected by the growing conditions; afforestation of organic soils reduces GHG emissions by almost 6 times over 40 years than afforestation of mineral soils. The reduction of GHG emissions from soil in organic soils is on average $86 \%$ of the total GHG emission reduction in forested areas.

3. Afforestation of mineral soils accounts for most of the GHG emission reductions in the first 40 years after plantation. Thereafter, the reduction of GHG emissions is significantly slower, and is ensured mainly by the accumulation of carbon in HWP and dead wood. In organic soils, the reduction of GHG emissions continues, but the expected effect may be influenced by the development of more accurate methods for accounting for GHG emissions.

4. The substitution effect of biofuels has an increasing role to play in reducing GHG emissions over time, assuming that wood products are recycled into biofuels at the end of their useful life.

5. Significant reduction of additional GHG emissions can be ensured by the use of selected planting material, increasing the yield of valuable timber in maintenance and restoration felling. Currently, only an average of $35 \%$ of wood is processed into timber.

6. When afforesting organic and moist soils, it is recommended to plant 1500 seedlings ha ${ }^{-1}$, but in fertile soils with optimal moisture regime -2000 seedlings ha $^{-1}$. Increasing the planting density to 2500 seedlings $\mathrm{ha}^{-1}$ increases $\mathrm{CO}_{2}$ removals during 40 years period, but it also significantly increases the risk of wind and other damage and reduces the output of valuable assortments.

\section{Acknowledgements}

The study is elaborated within the scope of the post-doctoral research project "Economic and environmental assessment of biomass production in buffer zones around drainage systems and territories surrounding the protective belts of natural water streams" (agreement No. 1.1.1.2/16/I/001, application No 1.1.1.2/VIAA/3/19/437).

\section{References}

[1] Doelman J.C., Stehfest E., Vuuren D.P. van, Tabeau A., et al., Afforestation for climate change mitigation: Potentials, risks and trade-offs. Global Change Biology 2020, 26, pp. 1576-1591.

[2] Kreidenweis U., Humpenöder F., Stevanovic M., Bodirsky B.L., et al., Afforestation to mitigate climate change: impacts on food prices under consideration of albedo effects. Environ. Res. Lett. 2016, 11, 085001, 2016. $12 \mathrm{p}$.

[3] Liepiņš K., Modelis iegūstamo sortimentu apjoma aprēķināšanai krājas kopšanas cirtēs bērzu plantācijās atkarībā no audzes parametriem (A model for calculation of output of different assortments in birch plantations depending from stand characteristics), Latvijas Valsts mežzinātnes institūts „Silava”, Salaspils, 2013. (In Latvian)

[4] Liepiņš K., Daugaviete M., Zālītis P. Bērza plantācijas lauksaimniecības zemēs (Birch plantations in farmlands), Latvijas Valsta mežzinātnes institūts „,Silava”, Salaspils, 2013. 93 p. (In Latvian)

[5] Līcīte I., Lupiķis A., Peters J., Butlers A., Armolaitis K., Soosaar K., Laiho R., Čiuldiene D., Jauhiainen J., Report on the identified climate change mitigation targeted management practices on organic soils, Latvia State Forest Research Institute "Silava," Salaspils, 2019. 119 p.

[6] Pilvere I., Latvijas Lauksaimniecības un Lauku attīstības SAPARD programmas paveiktā (Ex-post) novērtējums (Ex-post evaluation of the Latvian Agriculture and Rural Development SAPARD program), RISEBA, Rīga, 2007. 168 p. (In Latvian) 
[7] Daugaviete M., Lazdina D., Bambe B., Lazdins A., Makovskis K., Daugavietis U. Plantation Forests: A Guarantee of Sustainable Management of Abandoned and Marginal Farmlands, in: Energy Efficiency and Sustainable Lighting - a Bet for the Future, 2020: p. 34.

[8] Bērziņa L., Degola L., Grīnberga L., Kreišmane D., Lagzdiņš A., Lazdiņš A., Lēnerts A., Lupiķis A., Naglis-Liepa N., Popluga D., Rivža P., Sudārs R. Siltumnīcefekta gāzu emisiju samazināšanas iespējas ar klimatam draudzīgu lauksaimniecību un mežsaimniecību Latvijāa (Possibilities to reduce GHG emissions in Latvia by applying climate friendly measures in agriculture and forestry), SIA „Drukātava”, Jelgava, 2018. 153 pp. (In Latvian)

[9] Lazdiņš A., Šnepsts G., Petaja G., Kārkliṇa I., Verification of applicability of forest growth model AGM in elaboration of forestry projections for National forest reference level, in: Proceedings of the 9th International Scientific Conference Rural Development 2019, 2019. pp 289-294.

[10] AS "Latvijas valsts meži”. Sortimentu iznākums galvenajā un krājas kopšanas cirtē (Output of different assortments in thinning and regenerative felling), 2010. 64 p. (In Latvian)

[11] Bardule A., Lupikis A., Butlers A., Lazdins A. Organic carbon stock in different types of mineral soils in cropland and grassland in Latvia, Zemdirbyste-Agriculture, 104 2017. pp. 3-8.

[12] Liepiņš J., Lazdiņš A., Liepiņš K., Equations for estimating above- and belowground biomass of Norway spruce, Scots pine, birch spp. and European aspen in Latvia, Scandinavian Journal of Forest Research, 2017. pp. 1-43.

[13] Hiraishi T., Krug T., Tanabe K., Srivastava N., Fukuda M., Troxler T., Jamsranjav B. 2013 Supplement to the 2006 IPCC Guidelines for National Greenhouse Gas Inventories: Wetlands, IPCC, Switzerland, 2013. 354 pp.

[14] Ministry of Environmental Protection and Regional Development, Latvia's National Inventory Report Submission under UNFCCC and the Kyoto protocol Common Reporting Formats (CRF) 1990-2017, Ministry of Environmental Protection and Regional Development of the Republic of Latvia, Riga, 2019.

[15] Eggleston S., Buendia L., Miwa K., Ngara T., Kiyoto T., eds. 2006 IPCC Guidelines for National Greenhouse Gas Inventories. Agriculture, Forestry and Other Land Use, in: 2006 IPCC Guidelines for National Greenhouse Gas Inventories, Institute for Global Environmental Strategies (IGES), Japan, 2006. 678 p.

[16] Eggleston S., Buendia L., Miwa K., Ngara T., Tanade K. eds. 2006 IPCC guidelines for national greenhouse gas inventories Volume 2 Energy, The Institute for Global Environmental Strategies, Hayama-machi (Kanagawa-ken), 2006. 200 p. 